\title{
Canopy temperature and heat stress are increased by compound high air temperature and water stress and reduced by irrigation - a modeling analysis
}

\author{
Xiangyu Luan and Giulia Vico \\ Department of Crop Production Ecology, Swedish University of Agricultural Sciences (SLU), Uppsala, Sweden \\ Correspondence: Giulia Vico (giulia.vico@slu.se)
}

Received: 21 October 2020 - Discussion started: 28 October 2020

Revised: 26 January 2021 - Accepted: 28 January 2021 - Published: 24 March 2021

\begin{abstract}
Crop yield is reduced by heat and water stress and even more when these conditions co-occur. Yet, compound effects of air temperature and water availability on crop heat stress are poorly quantified. Existing crop models, by relying at least partially on empirical functions, cannot account for the feedbacks of plant traits and response to heat and water stress on canopy temperature. We developed a fully mechanistic model, coupling crop energy and water balances, to determine canopy temperature as a function of plant traits, stochastic environmental conditions, and irrigation applications. While general, the model was parameterized for wheat. Canopy temperature largely followed air temperature under well-watered conditions. But, when soil water potential was more negative than $-0.14 \mathrm{MPa}$, further reductions in soil water availability led to a rapid rise in canopy temperature - up to $10^{\circ} \mathrm{C}$ warmer than air at soil water potential of $-0.62 \mathrm{MPa}$. More intermittent precipitation led to higher canopy temperatures and longer periods of potentially damaging crop canopy temperatures. Irrigation applications aimed at keeping crops under well-watered conditions could reduce canopy temperature but in most cases were unable to maintain it below the threshold temperature for potential heat damage; the benefits of irrigation in terms of reduction of canopy temperature decreased as average air temperature increased. Hence, irrigation is only a partial solution to adapt to warmer and drier climates.
\end{abstract}

\section{Introduction}

High and stable crop yield requires suitable climatic conditions throughout the growing season. Abiotic stressors, like water scarcity and high temperatures, can adversely affect crop growth, development, and yield, as shown by controlled-condition and field experiments, large-scale surveys, and crop model applications (e.g., Zampieri et al., 2017; Daryanto et al., 2017; Kimball et al., 2016; Ray et al., 2015; Asseng et al., 2015). Both water and heat stress impair photosynthesis (Way and Yamori, 2014; Lawlor and Tezara, 2009), undermine crop growth (Hsiao, 1973; Hatfield and Prueger, 2015) and reproduction (Prasad et al., 2011), and hasten crop development and leaf senescence (Lobell et al., 2012), although the physiological mechanisms can differ (Fahad et al., 2017). Heat and water stress do not only act independently but also have compound effects on plant phenology and physiology, so heat stress is more detrimental if co-occurring with water stress (Mahrookashani et al., 2017; Prasad et al., 2011; Suzuki et al., 2014; Cohen et al., 2021). Yet, these compound effects of heat and water stress are seldom considered experimentally or via models (Rötter et al., 2018).

Climate change is projected to increase air temperature and, in many regions, decrease growing season precipitation or lengthen dry spells (IPCC, 2013). Hot and dry summers are becoming more common (Zscheischler and Seneviratne, 2017; Alizadeh et al., 2020), and changes in climate are already reducing and will likely further reduce crop yield and its stability and, ultimately, global food security (e.g., Challinor et al., 2014; Masson-Delmotte et al., 2018; Moore and Lobell, 2015; Rosenzweig et al., 2014). The frequency and 
severity of crop heat and water stress are directly affected by air temperature and soil water availability and indirectly driven by evapotranspiration, which is enhanced by warm temperatures. Nevertheless, how air temperature and precipitation and their variability interact in defining the occurrence, extent, and duration of crop heat and water stress has not been investigated in detail.

Canopy temperature allows more accurate estimates of the consequences of heat stress on the crop and its yield than air temperature (Gabaldón-Leal et al., 2016; Siebert et al., 2014; Rezaei et al., 2015). Canopy temperature can deviate from air temperature under field conditions because of the interplay among plant traits, plant water availability, air temperature and humidity, solar radiation, wind velocity, and the ensuing canopy microclimate (Michaletz et al., 2016; Schymanski et al., 2013). Considering canopy instead of air temperature is particularly important when characterizing the effects of compound heat and water stress and the mitigating potential of irrigation against heat stress because canopy temperature can be substantially higher than air temperature under water stress (e.g., Siebert et al., 2014).

Heat stress and damage are the result of complex and interacting plant physiological processes, depending on the temperature reached by the specific organ and the duration of the stress. Crop response to temperature is nonlinear (Porter and Gawith, 1999; Sanchez et al., 2014). Exceeding crop- and developmental-stage-specific thresholds can lead to plant tissue damage and halted physiological processes, although the plant can still survive. Also, the duration of exposure to high temperatures affects the outcome. For example, the accumulation of high temperature days negatively affected yield in rainfed systems (Schlenker and Roberts, 2009). In the face of increasing variability in the climatic conditions, we need to determine how stochastic precipitation and air temperature combine in determining canopy temperature. Average canopy temperatures and duration of periods above the threshold for damage can provide indications on the exposure of crops to potential heat stress.

Irrigation can buffer some aspects of climatic variability and extremes imposed on crop production (Tack et al., 2017; Zhang et al., 2015; Li and Troy, 2018; Vogel et al., 2019). Irrigation directly alleviates water stress by supplementing precipitation. Furthermore, by sustaining the plant's evaporative cooling, irrigation can reduce canopy temperature and, hence, the consequences of high air temperature (Vogel et al., 2019; Siebert et al., 2017). In other words, by removing water stress, irrigation can also diminish the occurrence of heat stress. Nevertheless, we lack a quantification of how much irrigation can reduce the effects of unfavorable air temperature and precipitation and the occurrence of crop heat stress and compound heat and water stress.

Canopy temperature is difficult to measure directly, although it can be estimated indirectly based on thermal imagery (e.g., Still et al., 2019). Models are a powerful tool for exploring how canopy temperature changes with growing conditions and plant traits beyond what is feasible via direct observations in specific experiments. Existing crop canopy temperature models either link canopy to growing conditions via simple empirical relations (e.g., Shao et al., 2019; Neukam et al., 2016) or explicitly model the leaf or canopy energy balance (Webber et al., 2016, 2017; Fang et al., 2014). But, so far, the role of plant water availability has been included only via semi-empirical corrections - even in mechanistic models. For example, actual canopy temperature was calculated based on canopy temperatures under maximum and zero stomatal conductances and a crop water stress index (for a review of approaches and their performance, see Webber et al., 2017, 2018). Mechanistic models fully representing plant physiology can estimate crop canopy temperature that better reflects soil water and weather dynamics and how plants respond to environmental conditions. Such models are currently lacking but are necessary for quantifying the effects of joint changes in air temperature and precipitation patterns and the benefits of irrigation.

We developed a mechanistic model to estimate crop canopy temperature as a function of crop physiology, soil features, and (stochastic) climatic conditions, coupling the canopy energy balance and the water transport through the soil-plant-atmosphere continuum (SPAC), with stomatal conductance based on an optimality principle. We used the model in a case study - wheat grown in a temperate climate - to answer the following questions:

- What are the compound effects of soil water availability and air temperature on crop canopy temperature?

- How does the precipitation pattern influence canopy temperature and its variability and the duration of potentially damaging canopy temperatures?

- How effective is irrigation in reducing canopy temperature and the duration of potentially damaging canopy temperatures, depending on the climatic regime?

\section{Methods}

\subsection{Model description}

To quantify the compound effects of air temperature and precipitation regimes on canopy temperature and the potential of irrigation to reduce the occurrence of crop heat stress, we developed a mechanistic model describing the coupled canopy energy and water balances and their interactions with the water balance of the rooting zone (see the model structure in Fig. 1 and the Supplement for details and symbols). The model allows us to explore how plant traits and physiological responses to growing conditions interact with air temperature and soil water availability in defining canopy temperature, while relying on parameters with clear physiological meanings (Table S2 in the Supplement). 


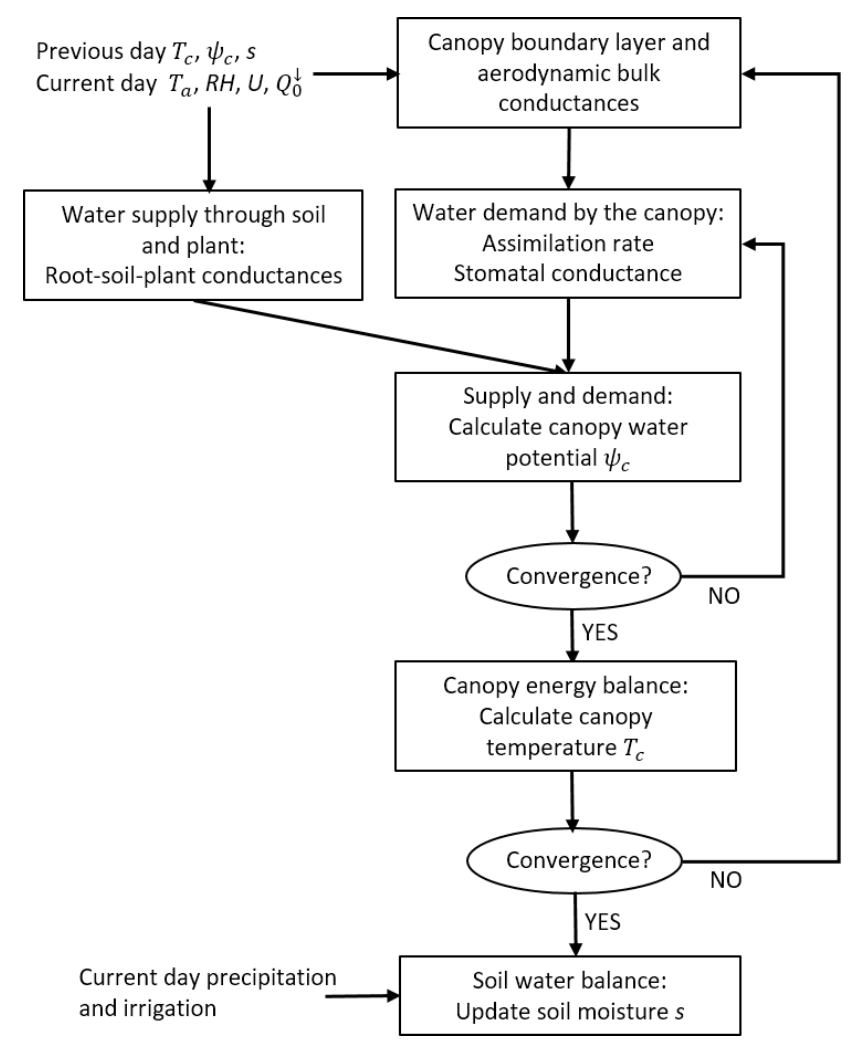

Figure 1. Flow diagram of the determination of canopy temperature and soil moisture dynamics.

To limit parameter and computational requirements, a minimalist approach was used, lumping the canopy in a big leaf model (Amthor, 1994; Jarvis and McNaughton, 1986; Bonan, 2019) and the soil water dynamics in a bucket-filling model, with instantaneous losses via runoff and percolation below the rooting zone (e.g., Milly, 1994; Rodriguez-Iturbe et al., 1999). These simplifications are expected to have minor repercussions on our conclusions (see Sect. S5 in the Supplement).

As detailed in the Supplement, combining the canopy water and energy balance, the canopy temperature, $T_{\mathrm{c}}$, can be obtained as follows:

$$
\begin{aligned}
& T_{\mathrm{c}}= \\
& T_{\mathrm{a}}+\frac{Q^{\downarrow}+B_{\mathrm{n}, \text { ref }}^{\downarrow}-\lambda g_{\mathrm{v}, \mathrm{c}} D}{c_{\mathrm{p}} g_{\mathrm{H}, \mathrm{c}}+\lambda g_{\mathrm{v}, \mathrm{c}} s_{s}+4 \varepsilon_{\mathrm{c}} \sigma T_{\mathrm{a}}^{3}\left[1-\exp \left(-K_{b l, d} L_{\mathrm{AI}}\right)\right]},
\end{aligned}
$$

where $T_{\mathrm{a}}$ is the air temperature, $Q \downarrow$ is the net absorbed shortwave radiation, $B_{\mathrm{n}}^{\downarrow}$ ref is the net absorbed longwave radiation at $T_{\mathrm{a}}$ (isothermal radiation), and $D$ is the atmospheric vapor pressure deficit. $g_{\mathrm{v}, \mathrm{c}}$ and $g_{\mathrm{H}, \mathrm{c}}$ are the total canopy conductances to water vapor and heat, respectively, which include stomatal and aerodynamic conductances, $\lambda, c_{\mathrm{p}}, \varepsilon_{\mathrm{c}}, \sigma$, and $K_{b l, d}$ are constants (Table S1), $s_{s}$ is the slope of the vapor pressure vs. temperature curve, dependent on $T_{\mathrm{a}}$, and $L_{\mathrm{AI}}$ is the leaf area index.

We explicitly included the dependence of stomatal conductance on environmental conditions and plant physiology, exploiting an optimality principle, namely that plants are assumed to maximize carbon uptake over a given period, subject to limited water availability (Mäkelä et al., 1996; Eqs. S9-S11 in the Supplement). We chose this approach because it is simple, yet based on an evolutionary principle, and has led to promising results (Buckley et al., 2017; Eller et al., 2020). Many stomatal optimization models based on water use efficiency assume that photosynthesis is limited either by RuBisCO (ribulose-1,5-bisphosphate carboxylaseoxygenase) or electron transport rate. To avoid this a priori assumption, we approximated the original Farquhar et al. (1980) model for the photosynthetic rate with a hyperbolic function that includes both limitations while retaining the same physiological parameters (Vico et al., 2013). This model was further developed here to account for the effects of the leaf boundary layer conductance and day respiration in addition to the key stomatal and non-stomatal effects of limited water availability on marginal water use efficiency and metabolic activity (Zhou et al., 2013; Manzoni et al., 2011; Vico and Porporato, 2008; see Sect. S1.2.1 for details). The results obtained with an alternative, empirical model of canopy conductance parameterized with eddy covariance data (Eqs. S30-S32; Novick et al., 2016) further support our mechanistic approach. But, they also highlight the need to explicitly represent canopy gas exchanges to capture the dependence of canopy temperature on air temperature, unless site-specific and crop-specific data are available to determine the canopy conductance empirically (Fig. S9). Finally, aerodynamic conductances to heat and vapor were determined based on wind velocity, $U$, and leaf width via well-established, semi-empirical relations describing heat and mass transport inside the leaf boundary layer and to the bulk atmosphere (Sects. S1.2.2 and S1.2.3).

The canopy conductances affect and are affected by the soil water balance and water transport along the SPAC. On the one hand, soil water potential influences leaf water potential and, hence, leaf physiological activities (stomatal conductance, metabolic rates, and marginal water use efficiency). On the other hand, stomatal conductance and atmospheric water demand drive the rate of canopy water losses and, hence, the decline of soil water content. We represented the soil water content as soil saturation, $s(0 \leq s \leq 1$; hereafter soil moisture), linked to soil water potential, $\psi_{s}$, via texture-dependent soil water retention curves (Eq. S24). A bucket-filling model was used to describe the soil moisture dynamics, with precipitation and irrigation as input and evapotranspiration, deep percolation below the rooting zone and surface runoff as losses but neglecting the root structure, the time needed for the water to be redistributed within the soil, and lateral soil water movements (Sect. S1.3.1; Vico and Porporato, 2010). The soil water balance was coupled to a min- 
imalist description of water transport through the SPAC to determine the leaf water potential. The SPAC was modeled as a series of conductances from the soil, through the plant, to the atmosphere (Sect. S1.3.2; Manzoni et al., 2013).

These model components provide conductances and boundary conditions to apply Eq. (1) and quantify how canopy temperature, $T_{\mathrm{c}}$, changes with environmental conditions and management, namely air temperature and humidity, wind velocity, incoming solar radiation, precipitation and irrigation applications, if any. The model needs to be solved iteratively (Fig. 1). At each time step (1 d; see Sect. 2.3), the model considers the previous soil moisture and current atmospheric conditions. The previous canopy temperature and water potential are used as initial guesses for the numerical integration. First, the model determines the canopy boundary layer and aerodynamic bulk conductances and water supply and demand. Then, the canopy water potential $\psi_{\mathrm{c}}$ is determined iteratively by equating water supply and demand. After convergence is reached on $\psi_{\mathrm{c}}$, the canopy energy balance is used to determine $T_{\mathrm{c}}$ iteratively. Finally, the soil water balance is updated with inputs and losses cumulated over the time step.

\subsection{Metrics of potential heat stress damage}

Based on $T_{\mathrm{c}}$, we derived the following two metrics representing the potential for heat stress damage: (i) $T_{\mathrm{c} \text {, mean }}$, the mean canopy temperature during a specific period (anthesis; see Sect. 2.3), and (ii) $P_{\mathrm{CHS}}$, the fraction of days during such a period when $T_{\mathrm{c}}$ exceeded the crop-specific threshold $T_{\mathrm{th}}$, above which detrimental effects of crop heat stress are likely. $P_{\mathrm{CHS}}$ is thus a measure of the duration of the detrimental conditions, while $T_{\mathrm{c} \text {, mean }}$ quantifies the level of detrimental conditions.

\subsection{Case study}

While the model is of general applicability, we focused on the case of wheat (Triticum aestivum) - a staple crop with relatively low tolerance to high temperatures when compared with other crops (Sanchez et al., 2014) - grown at $45^{\circ}$ N. All the model parameters are summarized in Table S2.

We restricted our analyses to anthesis, when wheat is most vulnerable to heat (Porter and Gawith, 1999) and water (Daryanto et al., 2017) stress. Anthesis was assumed to last $21 \mathrm{~d}$ (Mäkinen et al., 2018), starting on day 140 of the year, i.e., 20 May (in line with observations and simulations at the latitude selected; Semenov et al., 2014; Bogard et al., 2011). For simplicity, the timing and length of anthesis were kept constant under all climatic scenarios, regardless of irrigation applications.

The model is capable of simulating the diurnal course of the key variables, but, for simplicity, we focused on the central part of the day, when incoming shortwave radiation at the top of the canopy $Q_{0}^{\downarrow}$ and air temperature $T_{\mathrm{a}}$ are at or near their daily maxima and $T_{\mathrm{c}}$ is expected to peak. Wind velocity $U$ was assumed to be at the lowest end of its realistic range, and $Q_{0}^{\downarrow}$ to be that of clear sky conditions, thus providing the maximum expected $T_{\mathrm{c}}$ and a conservative estimate of the frequency of occurrence of potentially damaging temperatures.

Measured environmental conditions relative to a specific location could be used to force the model. Yet, here we employed synthetically generated environmental conditions, varying their parameters to systematically explore several climate scenarios. Daily precipitation was idealized as a marked Poisson process (Rodriguez-Iturbe et al., 1999), i.e., exponentially distributed interarrival times, with average frequency $\lambda_{\mathrm{p}}$. Event depth was also assumed to be exponentially distributed, with average $\alpha_{\mathrm{p}}$ (Sect. S1.4.2). The variability of $T_{\mathrm{a}}$ around its long-term average $\mu_{T_{\mathrm{a}}}$ was described via an Ornstein-Uhlenbeck process (Sect. S1.4.3; Benth and Benth, 2007). In line with the focus on the warmest part of the day, $T_{\mathrm{a}}$ is interpreted as the maximum daily air temperature. Finally, $U, Q_{0}^{\downarrow}$, and RH (relative humidity) were assumed to be constant during the simulations (Table S2), whereas air water vapor pressure, $e_{\mathrm{a}}$, and vapor pressure deficit, $D$, were calculated based on $T_{\mathrm{a}}$ (Campbell and Norman, 1998).

As baseline pedoclimatic conditions, we considered a sandy loam soil, an average precipitation frequency $\lambda_{\mathrm{p}}$ of $0.2 \mathrm{~d}^{-1}$, an average event depth $\alpha_{\mathrm{p}}$ of $8.2 \mathrm{~mm}$ (corresponding to an average annual precipitation total of $600 \mathrm{~mm}$ ), a longterm average air temperature $\mu_{T_{\mathrm{a}}}$ of $25^{\circ} \mathrm{C}$, an air temperature standard deviation of $3.6^{\circ} \mathrm{C}$, an air relative humidity $\mathrm{RH}$ of $40 \%$, a wind velocity $U$ of $4 \mathrm{~m} \mathrm{~s}^{-1}$, and a net incoming shortwave radiation $Q_{0}^{\downarrow}$ of $800 \mathrm{~W} \mathrm{~m}^{-2}$. We also explored additional pedoclimatic conditions. Specifically, we considered more extreme precipitation scenarios, comprising increasing precipitation from increasing precipitation frequency, and a constant average annual precipitation total, but with more intermittent precipitation, with a reduced average precipitation frequency $\left(\lambda_{\mathrm{p}}=0.07 \mathrm{~d}^{-1}\right)$ and increased average event depth $\left(\alpha_{\mathrm{p}}=23.5 \mathrm{~mm}\right)$. Long-term average air temperatures $\mu_{T_{\mathrm{a}}}$ of 20 and $30^{\circ} \mathrm{C}$ were also explored. Separate sensitivity analyses were run for the standard deviation of air temperature (Fig. S6), soil texture (Fig. S7), and $U, Q_{0}^{\downarrow}$, and RH (Fig. S8).

For the irrigated case, a demand-based (water) stressavoidance irrigation was considered whereby an irrigation application is triggered whenever soil water potential reached the intervention point, $\tilde{\psi}_{s}$ (Vico and Porporato, 2011). To ensure well-watered conditions, $\tilde{\psi}_{s}$ was set to $-0.07 \mathrm{MPa}$, i.e., just above the incipient water stress for wheat $(-0.1 \mathrm{MPa}$; Kalapos et al., 1996). Each irrigation application restored a preset target soil water potential, $\hat{\psi}_{s}$, set at $-0.01 \mathrm{MPa}$. The difference between the intervention point and the target soil water potential is large enough to allow the use of a traditional irrigation technology (e.g., sprinkler systems or surface irrigation; see Vico and Porporato, 2011 and references therein). 
Finally, the crop- and developmental-stage-specific temperature threshold above which detrimental effects of crop heat stress are likely, $T_{\mathrm{th}}$, was set equal to the maximum baseline (i.e., cardinal) temperature during anthesis. $T_{\text {th }}$ is a large source of large uncertainty when aiming at defining the occurrence of crop heat stress and its consequences on the crop and final yield (Siebert et al., 2017; Wanjura et al., 1992). Even within a specific developmental stage, there is a large variability in reported baseline and optimal temperatures because of differences in variety, growing conditions, and experimental approach. Furthermore, a crop's baseline and optimal temperatures are often defined based on air temperature, although plants respond to canopy or even organ temperature. As shown below, the differences between air and canopy temperatures can be large, particularly under limited plant water availability. To make the comparison between $T_{\mathrm{c}}$ and $T_{\text {th }}$ meaningful, we considered a maximum baseline temperature obtained under well-watered conditions and low $D$ and set $T_{\text {th }}$ equal to $30^{\circ} \mathrm{C}$ (Saini and Aspinall, 1982). This value is similar to those obtained in other experiments focusing on wheat (Porter and Gawith, 1999).

\subsection{Statistical tests}

The simulated canopy temperatures were not normally distributed, according to the Anderson-Darling test $(p<0.05)$. To test if median $T_{\mathrm{c} \text {, mean }}$ and $P_{\mathrm{CHS}}$ differed across scenarios, we employed the Mood test. And, to test the difference in their variances, we used the Brown-Forsythe test. The test results are summarized in Tables S3-S8. Differences are commented on when $p<0.05$.

\section{Results}

The stochasticity of air temperature, $T_{\mathrm{a}}$, and precipitation occurrence was mirrored by the erratic variations in soil moisture, $s$, and canopy temperature, $T_{\mathrm{c}}$, in the numerically simulated trajectories (exemplified in Fig. 2). $T_{\mathrm{c}}$ largely followed $T_{\mathrm{a}}$, but $s$ determined whether $T_{\mathrm{c}}$ was near or above $T_{\mathrm{a}}$. Under well-watered conditions, when $s$ ensured unconstrained transpiration, $T_{\mathrm{c}}$ was similar to or even occasionally lower than $T_{\mathrm{a}}$, whereas, when $s$ decreased, $T_{\mathrm{c}}$ became warmer than $T_{\mathrm{a}}$ (after approximately day 12 in Fig. 2). The evolution of $T_{\mathrm{c}}$ and other key physiological state variables, including stomatal conductance, photosynthesis, and canopy water potential, during a dry down is reported in Fig. S1.

Despite the complex mechanisms linking $T_{\mathrm{a}}$ and plant water availability to $T_{\mathfrak{c}}$, the resulting temperature difference $T_{\mathrm{c}}-T_{\mathrm{a}}$ followed a relatively simple pattern (Fig. 3). When $s$ was above 0.34 (corresponding to $\psi_{s}=-0.14 \mathrm{MPa}$ for the soil chosen), $T_{\mathrm{c}}$ was within 1 to $2^{\circ} \mathrm{C}$ of $T_{\mathrm{a}}$, with $T_{\mathrm{c}}<T_{\mathrm{a}}$ for $T_{\mathrm{a}}>25^{\circ} \mathrm{C}$. Conversely, for $s<0.34, T_{\mathrm{c}}-T_{\mathrm{a}}$ increased as $s$ declined, with increasing slope, from $1{ }^{\circ} \mathrm{C}$ at $s=0.34$ to $10^{\circ} \mathrm{C}$ at $s=0.25$ (corresponding to $\psi_{s}=-0.62 \mathrm{MPa}$ ), and

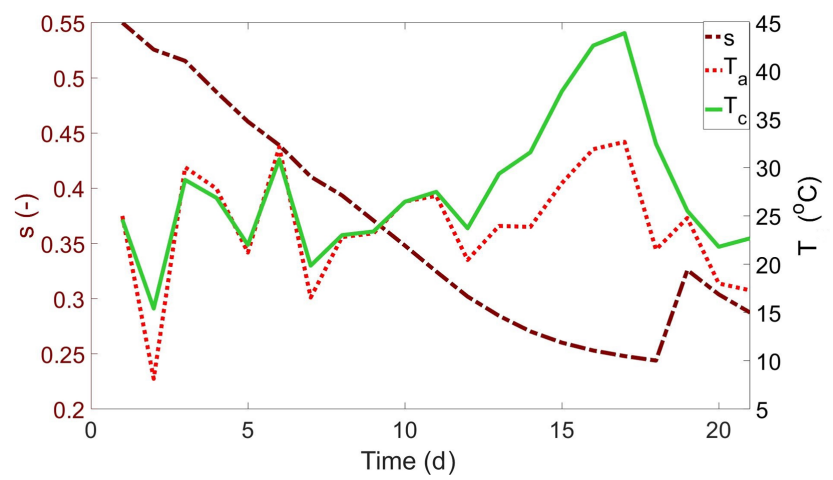

Figure 2. Example of numerically generated time series of soil moisture ( $s$; dot-dashed burgundy line), air temperature $\left(T_{\mathrm{a}}\right.$; dotted red line), and canopy temperature $\left(T_{\mathrm{c}}\right.$; solid green line), for rainfed cropping. The left axis represents soil moisture and the right axis temperature. The model was run for $21 \mathrm{~d}$ with the baseline environmental conditions. Parameter values are listed in Table S2.

$T_{\mathrm{c}}-T_{\mathrm{a}}$ was independent of $T_{\mathrm{a}}$ (i.e., under water stress, $T_{\mathrm{c}}-T_{\mathrm{a}}$ is driven by soil water availability for evaporative cooling). Hence, high $T_{\mathrm{c}}$ could be caused by high $T_{\mathrm{a}}$ or low $s$ or their combination. The dependence of the plant's physiological state variable on $s$ is reported in Fig. S2 for set $T_{\mathrm{a}}$.

Temperature and precipitation patterns interacted to define the mean canopy temperature during anthesis, $T_{\mathrm{c} \text {, mean }}$. Increasing average precipitation totals decreased median $T_{\mathrm{c} \text {, mean }}$ (colors in Fig. 4; Tables S3 and S4), particularly at lower precipitation totals (red in Fig. 4) and higher longterm average air temperature $\mu_{T_{\mathrm{a}}}$ (red hues in Fig. 4). $T_{\mathrm{c} \text {, mean }}$ was less affected by annual average precipitation totals larger than $900 \mathrm{~mm}$ and $\mu_{T_{\mathrm{a}}}$ at $20^{\circ} \mathrm{C}$. $T_{\mathrm{c} \text {, mean variability increased }}$ with $\mu_{T_{\mathrm{a}}}$ and, to a lesser extent, with decreasing average precipitation totals (Tables S3 and S4).

Precipitation regime affected median of $T_{\mathrm{c}, \text { mean }}$ and its variability even when considering the same precipitation total but different average precipitation frequencies, $\lambda_{\mathrm{p}}$ (and, hence, event depths, $\alpha_{\mathrm{p}}$; Fig. 5a). When compared with the baseline precipitation scenario (red bars), larger but more intermittent events (i.e., lower $\lambda_{\mathrm{p}}$ and higher $\alpha_{\mathrm{p}}$; violet bars) resulted in higher $T_{\mathrm{c} \text {, mean }}$ median and variability in rainfed cropping (Table S5). The median of $T_{\mathrm{c} \text {, mean }}$ increased with $\mu_{T_{\mathrm{a}}}$ regardless of rainfall pattern, whereas the variance was not significantly affected (Table S6).

Irrigation reduced the median and variance of $T_{\mathrm{c}}$ with respect to rainfed cropping under the same climatic scenario (red vs. blue hues in Fig. 5a). Also, the dependence of $T_{\mathrm{c}}$ on the precipitation pattern was reduced with irrigation (Table S5). Yet, despite the irrigation, median and variability of $T_{\mathrm{c}}$ increased with $\mu_{T_{\mathrm{a}}}$ (Table S6), although the increase in median $T_{\mathrm{c}}$ was less marked than that under rainfed cropping. 


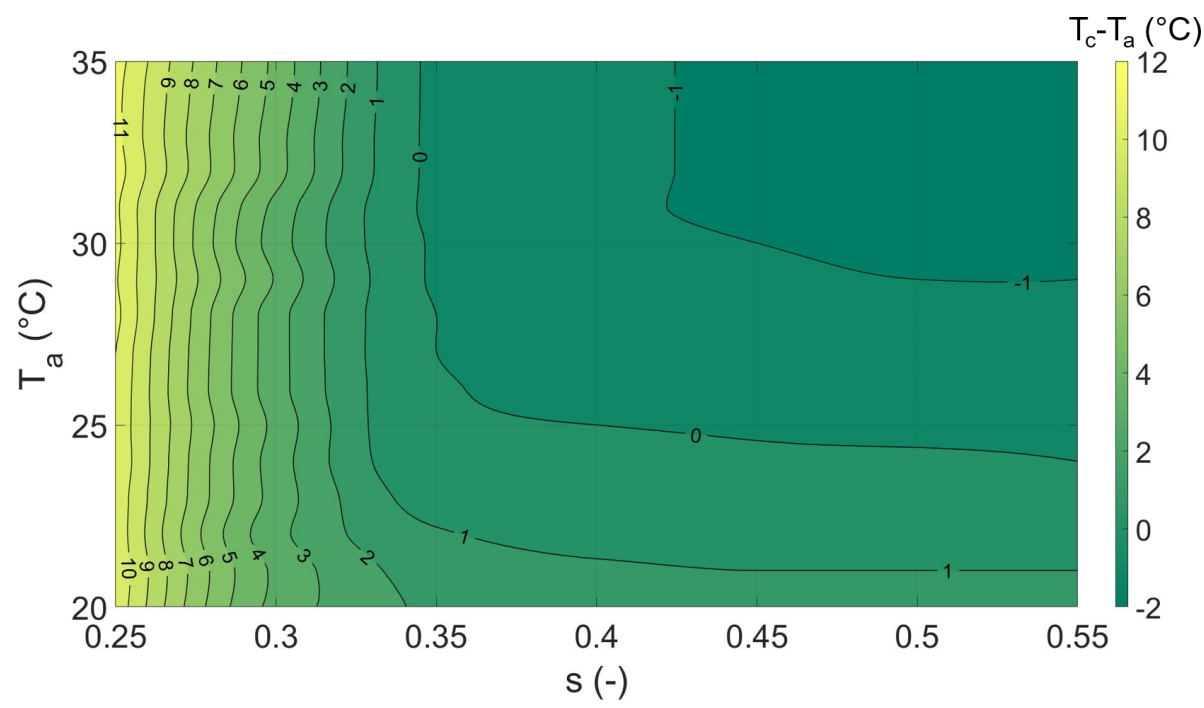

Figure 3. Canopy air temperature difference, $T_{\mathrm{c}}-T_{\mathrm{a}}$ (colors and contour lines), as a function of soil moisture ( $s ; x$ axis) and air temperature $\left(T_{\mathrm{a}} ; y\right.$ axis) for a sandy loam. All other parameters are summarized in Table S2.

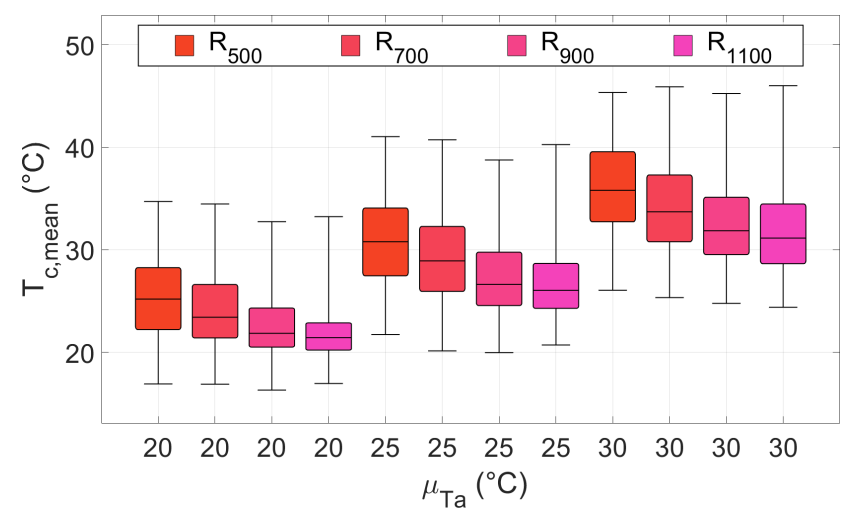

Figure 4. Distribution of mean canopy temperatures during anthesis, $T_{\mathrm{c}, \text { mean }}$, for four average annual precipitation totals $(500,700$, 900 , and $1110 \mathrm{~mm}$; colors) and three long-term average air temperatures $\mu_{T_{\mathrm{a}}}\left(20,25\right.$, and $30^{\circ} \mathrm{C} ; x$ axis). Average precipitation depth $\alpha_{\mathrm{p}}$ was kept at $15 \mathrm{~mm}$, while average precipitation frequency $\lambda_{\mathrm{p}}$ changed within each group of four bars, left to right, from 0.091 to $0.137,0.183$, and $0.228 \mathrm{~d}^{-1}$, leading to increasing average annual precipitation totals (subscripts in the legend). For each climatic scenario, 500 simulations of $21 \mathrm{~d}$ each were run. The horizontal black lines are the median values. The boxes extend from the first to the third quartile; whiskers cover the whole range.

Irrigation applications reduced the fraction of days during which $T_{\mathrm{c}}$ was above the threshold temperature for potential heat damage, $T_{\mathrm{th}}$, that is, of likely crop heat stress $\left(P_{\mathrm{CHS}}\right.$; Fig. 5b). But, it could not completely prevent this occurrence (i.e., median $P_{\mathrm{CHS}}>0$ ), except for $\mu_{T_{\mathrm{a}}}=20^{\circ} \mathrm{C}$. Among the climatic scenarios considered, the largest median reduction in $P_{\mathrm{CHS}}(100 \%)$ occurred at $\mu_{T_{\mathrm{a}}}=20^{\circ} \mathrm{C}$ and the smallest (between $53 \%$ and $58 \%$ ) at $\mu_{T_{\mathrm{a}}}=30^{\circ} \mathrm{C}$ (Table 1).
Table 1. Reduction in the potential for heat stress by irrigation, as summarized by the median reductions in $P_{\mathrm{CHS}}$ from rainfed cropping to stress avoidance irrigation, using rainfed as reference.

\begin{tabular}{|c|c|c|}
\hline$\mu_{T_{\mathrm{a}}}\left({ }^{\circ} \mathrm{C}\right)$ & $\begin{array}{l}\text { Baseline precipitation } \\
\text { regime } \\
\left(\alpha_{\mathrm{p}}=8.2 \mathrm{~mm}\right. \\
\left.\lambda_{\mathrm{p}}=0.2 \mathrm{~d}^{-1}\right)\end{array}$ & $\begin{array}{l}\text { More intermittent } \\
\text { precipitation } \\
\left(\alpha_{\mathrm{p}}=23.5 \mathrm{~mm}\right. \\
\left.\lambda_{\mathrm{p}}=0.07 \mathrm{~d}^{-1}\right)\end{array}$ \\
\hline 20 & $100 \%$ & $100 \%$ \\
\hline 25 & $78 \%$ & $80 \%$ \\
\hline 30 & $53 \%$ & $58 \%$ \\
\hline
\end{tabular}

Increasing air temperature variability left the median and variance of $T_{\mathrm{c} \text {, mean }}$ unaltered in rainfed cropping but increased them in irrigated cropping (Fig. S6, top, and Table S7). There, the removal of water stress via irrigation made the resulting canopy temperature more sensitive to the air temperature regime. The median of and variance in $\mathrm{P}_{\mathrm{CHS}}$ increased with temperature variability in the irrigated cropping (Fig. S6, bottom, and Table S7). Also, incoming shortwave radiation, $Q_{0}^{\downarrow}$, wind velocity, $U$, and air relative humidity $\mathrm{RH}$ affected $T_{\mathrm{c}}$ (Fig. S8). An increase in $Q_{0}^{\downarrow}$ increased $T_{\mathrm{c}}$, particularly at $s<0.35$. Decreasing $U$ enhanced $T_{\mathrm{c}}$ for $s<0.35$ but did not affect it when $s>0.35$. In contrast, $T_{\mathrm{c}}$ slightly increased with RH for $s>0.35$ but showed no response to it when $s<0.35$. Finer soil texture did not affect $T_{\mathrm{c} \text {, mean }}$ and $\mathrm{P}_{\mathrm{CHS}}$, although the difference between rainfall scenarios remained (Fig. S7 and Table S8). Also, rooting depth $Z_{\mathrm{r}}$ could affect $T_{\mathrm{c} \text {, mean }}$ and $\mathrm{P}_{\mathrm{CHS}}$. Yet, when considering a range of $Z_{r}$ compatible with observations for wheat (and annual crops in general; Jackson et al., 1996), the effects on $T_{\mathrm{c}}$, mean of reduced losses via deep percolation and runoff and stabilized 

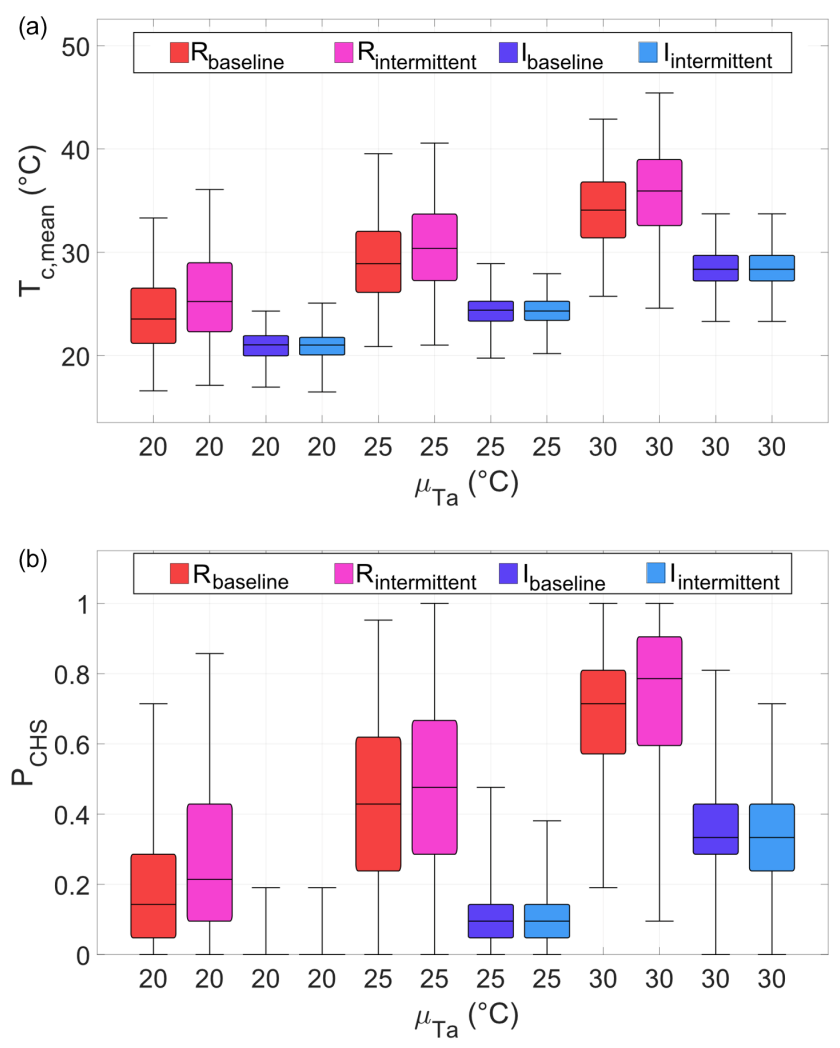

Figure 5. Distribution of mean canopy temperature during anthesis $\left(T_{\mathrm{c}}\right.$, mean $\left.;(\mathbf{a})\right)$ and percentage of days during which $T_{\mathrm{c}}$ is above the threshold temperature for potential heat damage, $T_{\mathrm{th}}\left(P_{\mathrm{CHS}}\right.$; (b)), under three long-term average air temperatures $\mu_{T_{\mathrm{a}}}$ ( $x$ axis) and different precipitation and irrigation scenarios (colors). In each group of four boxes, from left to right, $R_{\text {baseline }}$ and $R_{\text {intermittent }}$ represent rainfed cropping, respectively, under baseline precipitation $\left(\alpha_{\mathrm{p}}=8.2 \mathrm{~mm} ; \lambda_{\mathrm{p}}=0.2 \mathrm{~d}^{-1}\right)$ and more intermittent precipitation $\left(\alpha_{\mathrm{p}}=23.5 \mathrm{~mm} ; \lambda_{\mathrm{p}}=0.07 \mathrm{~d}^{-1}\right) . I_{\text {baseline }}$ and $I_{\text {intermittent }}$ refer to stress avoidance irrigation under the same precipitation regime of the corresponding rainfed cases. For each climatic scenario, 500 simulations of $21 \mathrm{~d}$ each were run. The horizontal black lines are the median values. The boxes extend from the first to the third quartile; whiskers cover the whole range.

soil moisture with deepening roots (Laio et al., 2001) were negligible (not shown).

\section{Discussion}

\subsection{Soil water availability and air temperature jointly affect canopy temperature}

We quantified the compound effect on canopy temperature from the following environmental conditions: air temperature, soil water availability, incoming shortwave radiation, wind velocity, relative humidity, soil texture, and irrigation. Our model is an improvement with respect to existing approaches which simulate canopy temperature in agricultural systems and rely on empirical corrections of values determined by means of the energy balance under extreme conditions (Fang et al., 2014; Webber et al., 2016). Lacking adequate modeling tools has limited our ability to effectively quantify the likelihood and extent of potential heat damage to crops and the potential improvements by irrigation.

The role of environmental conditions is mediated by plant physiology and its response to conditions. Indeed, losses via evapotranspiration dominated the soil water balance in all the climatic scenarios explored (see Sect. S3.1). But, despite the complex mechanisms behind canopy temperature, the resulting pattern was relatively simple. Canopy temperature increased from cooler temperatures and wetter soils to warmer and drier conditions (Fig. 3). Under well-watered conditions, some thermoregulation occurred, cooling down or warming up the canopy, depending on air temperature, to maintain the canopy near-optimal temperature for photosynthesis (Michaletz et al., 2016). This thermoregulation capability was lost when low water availability limited evaporative cooling. The differences in canopy and air temperatures provided by the model are in line with experimental observations and other model results, thus lending support to our approach. In wheat, for example, field observations and model results showed that daily maximum or mid-day canopy temperature was 2 to $10^{\circ} \mathrm{C}$ warmer than air under water stress and from 1 to $2{ }^{\circ} \mathrm{C}$ warmer to up to $6^{\circ} \mathrm{C}$ cooler than air temperature under well-watered conditions (Pinter et al., 1990; Rashid et al., 1999; Jensen et al., 1990; Howell et al., 1986; Ehrler et al., 1978; Balota et al., 2008; Neukam et al., 2016; Webber et al., 2016; Schittenhelm et al., 2014; Webber et al., 2018; Mon et al., 2016). Our simulations led to canopies being 2 to $10^{\circ} \mathrm{C}$ warmer than air under water stress and to a cooling effect of 1 to $2^{\circ} \mathrm{C}$ under warm but well-watered conditions. Differences between model results and observations can be ascribed to cultivar-specific traits, specific approach to measuring canopy temperature, measurement timing and position (within or just above the canopy), and environmental conditions (e.g., solar radiation and soil texture). Some of these aspects can be accounted for by the model, by adjusting the parameters to the specific crop and variety, and environmental conditions.

The difference between canopy and air temperature was higher than, and independent of, air temperature when soil water potential was below a critical value (Fig. 3). This threshold-like response mirrors that of stomatal closure and plant transpiration reduction with water stress (for wheat; e.g., Sadras and Milroy, 1996; Shen et al., 2002; Wang et al., 2008; Wu et al., 2011; Kalapos et al., 1996). Yet, no threshold for stomatal closure was imposed a priori in the model. The emerging threshold of soil water potential $(-0.14 \mathrm{MPa})$ is comparable with the soil water potential corresponding to incipient stomatal closure in some experiments $(-0.1 \mathrm{MPa}$; Kalapos et al., 1996) but higher than those of others (between -0.27 and $-0.35 \mathrm{MPa}$, depending on the cultivar; Wang et al., 2008) and lower than the value often assumed to cor- 
respond to well-watered conditions $(-0.03 \mathrm{MPa}$; Ali et al., 1999; Laio et al., 2001).

\subsection{More intermittent precipitation and higher air temperature increase canopy temperature}

Climate change is expected to alter both air temperature and precipitation regimes, with further increases in average and extremely high air temperatures and, in some regions, scarcer or more intermittent precipitation, i.e., longer dry spells (IPCC, 2013). Co-occurring dry and hot extremes are becoming increasingly frequent (Alizadeh et al., 2020; Zscheischler and Seneviratne, 2017). We showed that these compound changes can increase canopy temperature and its variability (Figs. 4 and 5).

For set air temperature conditions, even with same average precipitation totals, less frequent but larger precipitation events increased the median of and variance in canopy temperature, and the fraction of days during which the temperature threshold for potential heat damage was exceeded (Fig. 5). Larger, less frequent precipitation events result in enhanced losses via runoff and percolation below the rooting zone, thus reducing plant water availability. The ensuing (longer) dry down can lead to lower soil moisture levels, potentially enhancing canopy temperature. It is thus important to consider not only seasonal precipitation totals but also their timing. Indeed, reductions in the number of rainy days have already reduced crop yield and could even override the benefits of increased total precipitation (Ram, 2016). For a set precipitation regime, an increase in long-term average air temperature resulted not only in a higher mean canopy temperature during anthesis, as expected (Eq. 1), but also in a larger variability in such a mean (Figs. 4 and 5). These complex, compound effects show that it is necessary to explicitly consider not just the means but also the timing of and variability in air temperature and precipitation, and their joint effects, when quantifying the potential of climate change to cause crop heat stress. Hence, models accounting in full for the stochasticity of environmental conditions are needed.

Crops are also faced with increasing air carbon dioxide $\left(\mathrm{CO}_{2}\right)$ concentration. While this aspect of global change was not explored here, an increase in air $\mathrm{CO}_{2}$ concentration could reduce stomatal conductance and, thus, enhance canopy temperature when all the other conditions are the same. But, reduced stomatal conductance can also reduce the rate of soil water storage depletion and, thus, the maximum canopy temperature reached during a dry down. The net result of an increase in air $\mathrm{CO}_{2}$ concentration is expected to be small. Indeed, an air $\mathrm{CO}_{2}$ concentration of 200 to $220 \mathrm{ppm}$ (parts per million) above ambient conditions increased canopy temperature only up to $1{ }^{\circ} \mathrm{C}$ in free air $\mathrm{CO}_{2}$ enrichment experiments and model simulations (Webber et al., 2018), and a weak reduction in yield loss to heat with enhanced $\mathrm{CO}_{2}$ is expected (Schauberger et al., 2017).

\subsection{Irrigation reduces but does not cancel the risk of heat stress}

By reducing the occurrence and extent of water stress, irrigation could lower canopy temperature, and its variability, and the frequency of it exceeding the threshold for potential heat damage (Fig. 5). Irrigation can have positive effects on yields, not only by reducing water stress but also by reducing heat stress. Indeed, the canopy-to-air temperature difference is well correlated with the final yield (e.g., Blum, 1996; Reynolds et al., 1994; Thapa et al., 2018), except under extremely dry conditions (Schittenhelm et al., 2014). This temperature difference is often used for cultivar selection (Graß et al., 2020; Munns et al., 2010).

The extent of the reduction in canopy temperature and, hence, of the occurrence of potential heat stress even under stress-avoidance irrigation depended on the precipitation regime and long-term average air temperature. Irrigation was particularly effective in reducing canopy temperature and the duration of potentially damaging conditions at lower longterm average air temperature. And, for a set long-term average air temperature, irrigation was slightly more effective under more intermittent precipitation (Table 1). Yet, irrigation aiming at maintaining the plants under well-watered conditions could not completely remove the possibility that canopy temperature exceeded the temperature threshold for potential heat damage, except under the coolest air temperature scenario. Furthermore, the benefits of irrigation became smaller as air temperature increased. Irrigation could also have indirect effects on canopy temperature. At the regional scale, irrigation, by enhancing evaporation, can further reduce air temperature (e.g., Sacks et al., 2009; Lobell et al., 2008a) and canopy temperature, while lengthening developmental stages. These effects could be included by altering the air temperature regime (see Figs. 3 and 4 and Table 1 for the effects of average air temperature) and the duration of the anthesis.

The risk of canopy temperature exceeding the temperature threshold for potential heat damage under (water) stress avoidance irrigation can be interpreted as the potential heat stress attributable only to air temperature. This is because no limitation on evaporative cooling is expected under the imposed irrigation scenario, where the soil water potential triggering an irrigation application was less negative than the critical soil water potential emerging from Fig. 3. The reduction in the fraction of time in which canopy temperature is above the threshold for potential heat damage obtained via irrigation (Table 1) is a measure of the relative importance of air temperature and water stress in defining high canopy temperatures. In addition, for the most effective use of the available water resources against heat stress, the emerging threshold of soil water potential that limits waterstress-induced high canopy temperatures (Fig. 3) could be used to define a crop-specific irrigation intervention point for irrigation. Maintaining the soil water potential above that 
threshold would require additional water resources, while leading to marginal further cooling effects, i.e., little advantage in staving off heat stress.

Irrigation could not fully eliminate the negative effects of heatwaves and the warmer conditions expected in the future, but a widespread use of irrigation could directly or indirectly mitigate the effects of heatwaves (van der Velde et al., 2010). Nevertheless, even for air temperatures for which irrigation can reduce the potential for heat stress damage, and considering these regional effects, expanding irrigation to mitigate the effects of high canopy temperatures can be unadvisable or impossible due to physical or economic water scarcity (Rosa et al., 2020), already unsustainable exploitation of water resources (Wada et al., 2010), or the negative impacts of irrigation on soil salt content and nearby water bodies (Daliakopoulos et al., 2016; Scanlon et al., 2007). Other management approaches are, thus, needed to limit the potential for crop heat stress, particularly under high average air temperatures (Deryng et al., 2011; Lobell et al., 2008b). Examples are shifting to more heat-tolerant cultivars and species (Tack et al., 2016), altering the sowing date (Lobell et al., 2014; Mourtzinis et al., 2019), or migrating crops (Sloat et al., 2020) so that anthesis occurs when air temperature is, on average, lower.

\section{Conclusions}

Longer dry spells and high air temperatures are expected to become even more frequent in the future, with potential negative and compound effects on crop development and yield. Exploring the occurrence and severity of crop heat stress requires quantifying canopy temperature and considering under which conditions it exceeds the temperature threshold known to create appreciable damage. We developed a mechanistic model to determine canopy temperature, based on the explicit coupling of the soil water dynamics with the canopy energy balance, and an optimality principle for stomatal functioning, mechanistically accounting for plant physiology and its response to (stochastic) environmental conditions.

Using wheat as a case study, we explored how canopy temperature and its variability changed with stochastic air temperatures and precipitation in rainfed and irrigated cropping. When soil water potential was less negative than $-0.14 \mathrm{MPa}$, the additional benefit of an increase in soil water availability and, hence, potential evaporative cooling became marginal, and thermoregulation ensured semi-optimal leaf temperature. However, canopy temperature rose rapidly above air temperature when soil water potential was less than $-0.14 \mathrm{MPa}$, due to lowered evaporative cooling.

Less frequent and more intense precipitation caused more variable soil water contents, leading to higher and more variable canopy temperatures, and a higher fraction of days on which the temperature threshold for potential heat stress damage was exceeded. Larger precipitation totals and irrigation applications could reduce the occurrence of high canopy temperature and the potential for heat damage. Yet, irrigation could not completely remove the risk of crop heat stress when long-term average air temperature was $25^{\circ} \mathrm{C}$ or higher, calling for alternative management solutions.

Accurate estimates of canopy temperature are necessary to assess the role of precipitation and air temperature patterns in defining the risk of crop heat stress and to evaluate the mitigation potential of irrigation. Mechanistic models explicitly linking plant physiology to environmental conditions also allow the exploration of the effects of plant traits on the occurrence and extent of water and heat stress. As such, these models can support management decisions, from using the most beneficial irrigation applications to identifying crops able to avoid heat stress.

Code availability. The MATLAB 2018a code of the model is available at https://doi.org/10.5281/zenodo.4540738 (Vico and Luan, 2021).

Data availability. Data for model parameterization are available in the cited literature.

Supplement. The supplement related to this article is available online at: https://doi.org/10.5194/hess-25-1411-2021-supplement.

Author contributions. GV conceived the idea. XL and GV developed the codes of the model. XL performed the analyses and created the figures. XL and GV wrote the paper. GV revised the paper.

Competing interests. The authors declare that they have no conflict of interest.

Special issue statement. This article is part of the special issue "Understanding compound weather and climate events and related impacts (BG/ESD/HESS/NHESS inter-journal SI)". It is not associated with a conference.

Acknowledgements. We thank Maoya Bassiouni for feedback on the paper.

Financial support. This research has been supported by the Vetenskapsrådet (grant no. 2016-04910), the Svenska Forskningsrådet Formas (grant no. 2018-02872), and the 2018 JPI Joint Programming Initiative Water challenges for a changing world - Water Works 2017 ERA-NET Cofund (FORMAS; iAqueduct grant no. 2018-02787). 
Review statement. This paper was edited by Jakob Zscheischler and reviewed by Marijn van der Velde and one anonymous referee.

\section{References}

Ali, M., Jensen, C., Mogensen, V., and Bahrun, A.: Drought adaptation of field grown wheat in relation to soil physical conditions, Plant Soil, 208, 149-159, https://doi.org/10.1023/A:1004535819197, 1999.

Alizadeh, M. R., Adamowski, J., Nikoo, M. R., AghaKouchak, A., Dennison, P., and Sadegh, M.: A century of observations reveals increasing likelihood of continentalscale compound dry-hot extremes, Sci. Adv., 6, eaz4571, https://doi.org/10.1126/sciadv.aaz4571, 2020.

Amthor, J. S.: Scaling $\mathrm{CO}_{2}$-photosynthesis relationships from the leaf to the canopy, Photosynth. Res., 39, 321-350, https://doi.org/10.1007/bf00014590, 1994.

Asseng, S., Ewert, F., Martre, P., Rötter, R. P., Lobell, D. B., Cammarano, D., Kimball, B. A., Ottman, M. J., Wall, G. W., White, J. W., Reynolds, M. P., Alderman, P. D., Prasad, P. V. V., Aggarwal, P. K., Anothai, J., Basso, B., Biernath, C., Challinor, A. J., De Sanctis, G., Doltra, J., Fereres, E., Garcia-Vila, M., Gayler, S., Hoogenboom, G., Hunt, L. A., Izaurralde, R. C., Jabloun, M., Jones, C. D., Kersebaum, K. C., Koehler, A. K., Müller, C., Naresh Kumar, S., Nendel, C., O’Leary, G., Olesen, J. E., Palosuo, T., Priesack, E., Eyshi Rezaei, E., Ruane, A. C., Semenov, M. A., Shcherbak, I., Stöckle, C., Stratonovitch, P., Streck, T., Supit, I., Tao, F., Thorburn, P. J., Waha, K., Wang, E., Wallach, D., Wolf, J., Zhao, Z., and Zhu, Y.: Rising temperatures reduce global wheat production, Nat. Clim. Change, 5, 143-147, https://doi.org/10.1038/nclimate2470, 2015.

Balota, M., Payne, W. A., Evett, S. R., and Peters, T. R.: Morphological and physiological traits associated with canopy temperature depression in three closely related wheat lines, Crop Sci., 48, 1897-1910, https://doi.org/10.2135/cropsci2007.06.0317, 2008.

Benth, F. E. and Benth, J. S.: The volatility of temperature and pricing of weather derivatives, Quant. Financ., 7, 553-561, https://doi.org/10.1080/14697680601155334, 2007.

Blum, A.: Crop responses to drought and the interpretation of adaptation, in: Drought tolerance in higher plants: Genetical, physiological and molecular biological analysis, Springer, New York City, USA, 57-70, 1996.

Bogard, M., Jourdan, M., Allard, V., Martre, P., Perretant, M. R., Ravel, C., Heumez, E., Orford, S., Snape, J., and Griffiths, S.: Anthesis date mainly explained correlations between post-anthesis leaf senescence, grain yield, and grain protein concentration in a winter wheat population segregating for flowering time QTLs, J. Exp. Bot., 62, 3621-3636, https://doi.org/10.1093/jxb/err061, 2011.

Bonan, G.: Climate change and terrestrial ecosystem modeling, Cambridge University Press, Cambridge, UK, xx+438 pp., 2019.

Buckley, T. N., Sack, L., and Farquhar, G. D.: Optimal plant water economy, Plant Cell Environ., 40, 881-896, https://doi.org/10.1111/pce.12823, 2017.

Campbell, G. S. and Norman, J. M.: An introduction to environmental biophysics, Springer, New York City, USA, xv+286 pp., 1998.
Challinor, A. J., Watson, J., Lobell, D. B., Howden, S. M., Smith, D. R., and Chhetri, N.: A meta-analysis of crop yield under climate change and adaptation, Nat. Clim. Change, 4, 287-291, https://doi.org/10.1038/Nclimate2153, 2014.

Cohen, I., Zandalinas, S. I., Huck, C., Fritschi, F. B., and Mittler, R.: Meta-analysis of drought and heat stress combination impact on crop yield and yield components, Physiol. Plantarum, 171, 66-76, https://doi.org/10.1111/ppl.13203, 2021.

Daliakopoulos, I., Tsanis, I., Koutroulis, A., Kourgialas, N., Varouchakis, A., Karatzas, G., and Ritsema, C.: The threat of soil salinity: A European scale review, Sci. Total Environ., 573, 727-739, https://doi.org/10.1016/j.scitotenv.2016.08.177, 2016.

Daryanto, S., Wang, L., and Jacinthe, P.-A.: Global synthesis of drought effects on cereal, legume, tuber and root crops production: A review, Agr. Water Manage., 179, 18-33, https://doi.org/10.1016/j.agwat.2016.04.022, 2017.

Deryng, D., Sacks, W. J., Barford, C. C., and Ramankutty, N.: Simulating the effects of climate and agricultural management practices on global crop yield, Global Biogeochem. Cy., 25, GB2006, https://doi.org/10.1029/2009GB003765, 2011.

Ehrler, W., Idso, S., Jackson, R. D., and Reginato, R.: Wheat canopy temperature: Relation to plant water potential, Agron. J., 70, 251-256, https://doi.org/10.2134/agronj1978.00021962007000020010x, 1978.

Eller, C. B., Rowland, L., Mencuccini, M., Rosas, T., Williams, K., Harper, A., Medlyn, B. E., Wagner, Y., Klein, T., Teodoro, G. S., Oliveira, R. S., Matos, I. S., Rosado, B. H. P., Fuchs, K., Wohlfahrt, G., Montagnani, L., Meir, P., Sitch, S., and Cox, P. M.: Stomatal optimization based on xylem hydraulics (SOX) improves land surface model simulation of vegetation responses to climate, New Phytol., 226, 1622-1637, https://doi.org/10.1111/nph.16419, 2020.

Fahad, S., Bajwa, A. A., Nazir, U., Anjum, S. A., Farooq, A., Zohaib, A., Sadia, S., Nasim, W., Adkins, S., Saud, S., Ihsan, M. Z., Alharby, H., Wu, C., Wang, D., and Huang, J.: Crop production under drought and heat stress: Plant responses and management options, Front. Plant Sci., 8, 1147, https://doi.org/10.3389/fpls.2017.01147, 2017.

Fang, Q. X., Ma, L., Flerchinger, G. N., Qi, Z., Ahuja, L. R., Xing, H. T., Li, J., and Yu, Q.: Modeling evapotranspiration and energy balance in a wheat-maize cropping system using the revised RZ-SHAW model, Agr. Forest Meteorol., 194, 218-229, https://doi.org/10.1016/j.agrformet.2014.04.009, 2014.

Farquhar, G., von Caemmerer, S., and Berry, J.: A biochemical model of photosynthetic $\mathrm{CO}_{2}$ assimilation in leaves of C3 species, Planta, 149, 78-90, https://doi.org/10.1007/BF00386231, 1980.

Gabaldón-Leal, C., Webber, H., Otegui, M., Slafer, G., Ordóñez, R., Gaiser, T., Lorite, I., Ruiz-Ramos, M., and Ewert, F.: Modelling the impact of heat stress on maize yield formation, Field Crop Res., 198, 226-237, https://doi.org/10.1016/j.fcr.2016.08.013, 2016.

Graß, R., Böttcher, U., Lilienthal, H., Wilde, P., and Kage, H.: Is canopy temperature suitable for high throughput field phenotyping of drought resistance of winter rye in temperate climate?, Eur. J. Agron., 120, 126104, https://doi.org/10.1016/j.eja.2020.126104, 2020. 
Hatfield, J. L. and Prueger, J. H.: Temperature extremes: Effect on plant growth and development, Weather Clim. Extremes, 10, 410, https://doi.org/10.1016/j.wace.2015.08.001, 2015.

Howell, T., Musick, J., and Tolk, J.: Canopy temperature of irrigated winter wheat, T. ASAE, 29, 1692-1698, https://doi.org/10.13031/2013.30375, 1986.

Hsiao, T. C.: Plant responses to water stress, Ann. Rev. Plant Physio., 24, 519-570, https://doi.org/10.1146/annurev.pp.24.060173.002511, 1973.

IPCC: Climate Change 2013: The Physical Science Basis. Contribution of Working Group I to the Fifth Assessment Report of the Intergovernmental Panel on Climate Change, Cambridge University Press, Cambridge, UK, and New York, NY, USA, 1535, 2013.

Jackson, R. B., Canadell, J., Ehleringer, J. R., Mooney, H. A., Sala, O. E., and Schulze, E. D.: A global analysis of root distributions for terrestrial biomes, Oecologia, 108, 389-411, https://doi.org/10.1007/BF00333714, 1996.

Jarvis, P. G. and McNaughton, K. G.: Stomatal control of transpiration: Scaling up from leaf to region, in: Advances in Ecological Research, edited by: MacFadyen, A. and Ford, E. D., Academic Press, Cambridge, USA, 1-49, 1986.

Jensen, H., Svendsen, H., Jensen, S., and Mogensen, V.: Canopyair temperature of crops grown under different irrigation regimes in a temperate humid climate, Irrigation Sci., 11, 181-188, https://doi.org/10.1007/BF00189456, 1990.

Kalapos, T., van den Boogaard, R., and Lambers, H.: Effect of soil drying on growth, biomass allocation and leaf gas exchange of two annual grass species, Plant Soil, 185, 137-149, https://doi.org/10.1007/BF02257570, 1996.

Kimball, B. A., White, J. W., Wall, G., and Ottman, M. J.: Wheat responses to a wide range of temperatures: The hot serial cereal experiment, in: Improving Modeling Tools to Assess Climate Change Effects on Crop Response, edited by: Hatfield, J. and Fleisher, D., ASA, CSSA, SSSA, 3344, https://doi.org/10.2134/advagricsystmodel2137.2014.0014, 2016.

Laio, F., Porporato, A., Ridolfi, L., and Rodriguez-Iturbe, I.: Plants in water-controlled ecosystems: active role in hydrologic processes and response to water stress - II. Probabilistic soil moisture dynamics, Adv. Water Resour., 24, 707-723, https://doi.org/10.1016/s0309-1708(01)00005-7, 2001.

Lawlor, D. W. and Tezara, W.: Causes of decreased photosynthetic rate and metabolic capacity in water-deficient leaf cells: a critical evaluation of mechanisms and integration of processes, Ann. Bot.-London, 103, 561-579, https://doi.org/10.1093/aob/mcn244, 2009.

Li, X. and Troy, T. J.: Changes in rainfed and irrigated crop yield response to climate in the western US, Environ. Res. Lett., 13, 064031, https://doi.org/10.1088/1748-9326/aac4b1, 2018.

Lobell, D. B., Bonfils, C. J., Kueppers, L. M., and Snyder, M. A.: Irrigation cooling effect on temperature and heat index extremes, Geophys. Res. Lett., 35, L09705, https://doi.org/10.1029/2008GL034145, 2008a.

Lobell, D. B., Burke, M. B., Tebaldi, C., Mastrandrea, M. D., Falcon, W. P., and Naylor, R. L.: Prioritizing Climate Change Adaptation Needs for Food Security in 2030, Science, 319, 607-610, https://doi.org/10.1126/science.1152339, 2008b.
Lobell, D. B., Sibley, A., and Ortiz-Monasterio, J. I.: Extreme heat effects on wheat senescence in India, Nat. Clim. Change, 2, 186189, https://doi.org/10.1038/nclimate1356, 2012.

Lobell, D. B., Roberts, M. J., Schlenker, W., Braun, N., Little, B. B., Rejesus, R. M., and Hammer, G. L.: Greater Sensitivity to Drought Accompanies Maize Yield Increase in the U.S. Midwest, Science, 344, 516-519, https://doi.org/10.1126/science.1251423, 2014.

Mahrookashani, A., Siebert, S., Huging, H., and Ewert, F.: Independent and combined effects of high temperature and drought stress around anthesis on wheat, J. Agron. Crop Sci., 203, 453463, https://doi.org/10.1111/jac.12218, 2017.

Mäkelä, A., Berninger, F., and Hari, P.: Optimal control of gas exchange during drought: Theoretical analysis, Ann. Bot.-London, 77, 461-467, https://doi.org/10.1006/anbo.1996.0056, 1996.

Mäkinen, H., Kaseva, J., Trnka, M., Balek, J., Kersebaum, K. C., Nendel, C., Gobin, A., Olesen, J. E., Bindi, M., Ferrise, R., Moriondo, M., Rodríguez, A., Ruiz-Ramos, M., Takáč, J., Bezák, P., Ventrella, D., Ruget, F., Capellades, G., and Kahiluoto, H.: Sensitivity of European wheat to extreme weather, Field Crop. Res., 222, 209-217, https://doi.org/10.1016/j.fcr.2017.11.008, 2018.

Manzoni, S., Vico, G., Katul, G., Fay, P. A., Polley, W., Palmroth, S., and Porporato, A.: Optimizing stomatal conductance for maximum carbon gain under water stress: a meta-analysis across plant functional types and climates, Funct. Ecol., 25, 456-467, https://doi.org/10.1111/j.1365-2435.2010.01822.x, 2011.

Manzoni, S., Vico, G., Porporato, A., and Katul, G.: Biological constraints on water transport in the soil-plantatmosphere system, Adv. Water Resour., 51, 292-304, https://doi.org/10.1016/j.advwatres.2012.03.016, 2013.

Masson-Delmotte, V., Zhai, P., Pörtner, H.-O., Roberts, D., Skea, J., Shukla, P., Pirani, A., Moufouma-Okia, W., Péan, C., and Pidcock, R.: Global warming of $1.5^{\circ} \mathrm{C}$ : An IPCC special report on the impacts of global warming of $1.5^{\circ} \mathrm{C}$ above pre-industrial levels and related global greenhouse gas emission pathways, in the context of strengthening the global response to the threat of climate change, sustainable development, and efforts to eradicate poverty, World Meteorological Organization Geneva, Switzerland, 2018.

Michaletz, S. T., Weiser, M. D., McDowell, N. G., Zhou, J., Kaspari, M., Helliker, B. R., and Enquist, B. J.: The energetic and carbon economic origins of leaf thermoregulation, Nat. Plants, 2, 16129, https://doi.org/10.1038/nplants.2016.129, 2016.

Milly, P.: Climate, soil water storage, and the average annual water balance, Water Resour. Res., 30, 2143-2156, https://doi.org/10.1029/94WR00586, 1994.

Mon, J., Bronson, K. F., Hunsaker, D. J., Thorp, K. R., White, J. W., and French, A. N.: Interactive effects of nitrogen fertilization and irrigation on grain yield, canopy temperature, and nitrogen use efficiency in overhead sprinklerirrigated durum wheat, Field Crop Res., 191, 54-65, https://doi.org/10.1016/j.fcr.2016.02.011, 2016.

Moore, F. C. and Lobell, D. B.: The fingerprint of climate trends on European crop yields, P. Natl. Acad. Sci. USA, 112, 2670-2675, https://doi.org/10.1073/pnas.1409606112, 2015.

Mourtzinis, S., Specht, J. E., and Conley, S. P.: Defining optimal soybean sowing dates across the US, Sci. Rep.-UK, 9, 2800, https://doi.org/10.1038/s41598-019-38971-3, 2019. 
Munns, R., James, R. A., Sirault, X. R. R., Furbank, R. T., and Jones, H. G.: New phenotyping methods for screening wheat and barley for beneficial responses to water deficit, J. Exp. Bot., 61, 3499-3507, https://doi.org/10.1093/jxb/erq199, 2010.

Neukam, D., Ahrends, H., Luig, A., Manderscheid, R., and Kage, H.: Integrating wheat canopy temperatures in crop system models, Agronomy, 6, https://doi.org/10.3390/agronomy6010007, 2016.

Novick, K. A., Ficklin, D. L., Stoy, P. C., Williams, C. A., Bohrer, G., Oishi, A. C., Papuga, S. A., Blanken, P. D., Noormets, A., Sulman, B. N., Scott, R. L., Wang, L., and Phillips, R. P.: The increasing importance of atmospheric demand for ecosystem water and carbon fluxes, Nat. Clim. Change, 6, 1023, https://doi.org/10.1038/nclimate3114, 2016.

Pinter, P. J., Zipoli, G., Reginato, R. J., Jackson, R. D., Idso, S. B., and Hohman, J. P.: Canopy temperature as an indicator of differential water use and yield performance among wheat cultivars, Agr. Water Manage., 18, 35-48, https://doi.org/10.1016/03783774(90)90034-V, 1990.

Porter, J. R. and Gawith, M.: Temperatures and the growth and development of wheat: a review, Eur. J. Agron., 10, 23-36, https://doi.org/10.1016/s1161-0301(98)00047-1, 1999.

Prasad, P. V. V., Pisipati, S. R., Momcilovic, I., and Ristic, Z.: Independent and combined effects of high temperature and drought stress during grain filling on plant yield and chloroplast EF-Tu expression in spring wheat, J. Agron. Crop Sci., 197, 430-441, https://doi.org/10.1111/j.1439-037X.2011.00477.x, 2011.

Ram, F.: More uneven distributions overturn benefits of higher precipitation for crop yields, Environ. Res. Lett., 11, 024004, https://doi.org/10.1088/1748-9326/11/2/024004, 2016.

Rashid, A., Stark, J. C., Tanveer, A., and Mustafa, T.: Use of canopy temperature measurements as a screening tool for drought tolerance in spring wheat, J. Agron. Crop Sci., 182, 231-238, https://doi.org/10.1046/j.1439-037x.1999.00335.x, 1999.

Ray, D. K., Gerber, J. S., MacDonald, G. K., and West, P. C.: Climate variation explains a third of global crop yield variability, Nat. Commun., 6, 5989, https://doi.org/10.1038/ncomms6989, 2015.

Reynolds, M., Balota, M., Delgado, M., Amani, I., and Fischer, R.: Physiological and morphological traits associated with spring wheat yield under hot, irrigated conditions, Funct. Plant Biol., 21, 717-730, https://doi.org/10.1071/PP9940717, 1994.

Rezaei, E. E., Webber, H., Gaiser, T., Naab, J., and Ewert, F.: Heat stress in cereals: mechanisms and modelling, Eur. J. Agron., 64, 98-113, https://doi.org/10.1016/j.eja.2014.10.003, 2015.

Rodriguez-Iturbe, I., Porporato, A., Ridolfi, L., Isham, V., and Cox, D.: Probabilistic modelling of water balance at a point: the role of climate, soil and vegetation, P. Roy. Soc. Lond. A Mat., 455, 3789-3805, https://doi.org/10.1098/rspa.1999.0477, 1999.

Rosa, L., Chiarelli, D. D., Rulli, M. C., Dell'Angelo, J., and D'Odorico, P.: Global agricultural economic water scarcity, Sci. Adv., 6, eaaz6031, https://doi.org/10.1126/sciadv.aaz6031, 2020.

Rosenzweig, C., Elliott, J., Deryng, D., Ruane, A. C., Muller, C., Arneth, A., Boote, K. J., Folberth, C., Glotter, M., Khabarov, N., Neumann, K., Piontek, F., Pugh, T. A. M., Schmid, E., Stehfest, E., Yang, H., and Jones, J. W.: Assessing agricultural risks of climate change in the 21 st century in a global gridded crop model intercomparison, P. Natl. Acad. Sci. USA, 111, 32683273, https://doi.org/10.1073/pnas.1222463110, 2014.
Rötter, R. P., Appiah, M., Fichtler, E., Kersebaum, K. C., Trnka, M., and Hoffmann, M. P.: Linking modelling and experimentation to better capture crop impacts of agroclimatic extremes-A review, Field Crop Res., 221, 142-156, https://doi.org/10.1016/j.fcr.2018.02.023, 2018.

Sacks, W. J., Cook, B. I., Buenning, N., Levis, S., and Helkowski, J. H.: Effects of global irrigation on the near-surface climate, Clim. Dynam., 33, 159-175, https://doi.org/10.1007/s00382008-0445-z, 2009.

Sadras, V. O. and Milroy, S. P.: Soil-water thresholds for the responses of leaf expansion and gas exchange: A review, Field Crop Res., 47, 253-266, https://doi.org/10.1016/03784290(96)00014-7, 1996.

Saini, H. S. and Aspinall, D.: Abnormal sporogenesis in wheat (Triticum aestivum L.) induced by short periods of high temperature, Ann. Bot.-London, 49, 835-846, https://doi.org/10.1093/oxfordjournals.aob.a086310, 1982.

Sanchez, B., Rasmussen, A., and Porter, J. R.: Temperatures and the growth and development of maize and rice: a review, Global Change Biol., 20, 408-417, https://doi.org/10.1111/gcb.12389, 2014.

Scanlon, B. R., Jolly, I., Sophocleous, M., and Zhang, L.: Global impacts of conversions from natural to agricultural ecosystems on water resources: Quantity versus quality, Water Resour. Res., 43, W03437, https://doi.org/10.1029/2006wr005486, 2007.

Schauberger, B., Archontoulis, S., Arneth, A., Balkovic, J., Ciais, P., Deryng, D., Elliott, J., Folberth, C., Khabarov, N., Muller, C., Pugh, T. A. M., Rolinski, S., Schaphoff, S., Schmid, E., Wang, X. H., Schlenker, W., and Frieler, K.: Consistent negative response of US crops to high temperatures in observations and crop models, Nat. Commun., 8, 9, https://doi.org/10.1038/ncomms13931, 2017.

Schittenhelm, S., Kraft, M., and Wittich, K.-P.: Performance of winter cereals grown on field-stored soil moisture only, Eur. J. Agron., 52, 247-258, https://doi.org/10.1016/j.eja.2013.08.010, 2014.

Schlenker, W. and Roberts, M. J.: Nonlinear temperature effects indicate severe damages to US crop yields under climate change, P. Natl. Acad. Sci. USA, 106, 15594-15598, https://doi.org/10.1073/pnas.0906865106, 2009.

Schymanski, S. J., Or, D., and Zwieniecki, M.: Stomatal control and leaf thermal and hydraulic capacitances under rapid environmental fluctuations, Plos One, 8, e54231, https://doi.org/10.1371/journal.pone.0054231, 2013.

Semenov, M. A., Stratonovitch, P., Alghabari, F., and Gooding, M. J.: Adapting wheat in Europe for climate change, J. Cereal Sci., 59, 245-256, https://doi.org/10.1016/j.jcs.2014.01.006, 2014.

Shao, Q., Bange, M., Mahan, J., Jin, H., Jamali, H., Zheng, B., and Chapman, S. C.: A new probabilistic forecasting model for canopy temperature with consideration of periodicity and parameter variation, Agr. Forest Meteorol., 265, 88-98, https://doi.org/10.1016/j.agrformet.2018.11.013, 2019.

Shen, Y., Kondoh, A., Tang, C., Zhang, Y., Chen, J., Li, W., Sakura, Y., Liu, C., Tanaka, T., and Shimada, J.: Measurement and analysis of evapotranspiration and surface conductance of a wheat canopy, Hydrol. Process., 16, 2173-2187, https://doi.org/10.1002/hyp.1149, 2002.

Siebert, S., Ewert, F., Rezaei, E. E., Kage, H., and Grass, R.: Impact of heat stress on crop yield-on the importance of con- 
sidering canopy temperature, Environ. Res. Lett., 9, 044012, https://doi.org/10.1088/1748-9326/9/4/044012, 2014.

Siebert, S., Webber, H., Zhao, G., and Ewert, F.: Heat stress is overestimated in climate impact studies for irrigated agriculture, Environ. Res. Lett., 12, 054023, https://doi.org/10.1088/17489326/aa702f, 2017.

Sloat, L. L., Davis, S. J., Gerber, J. S., Moore, F. C., Ray, D. K., West, P. C., and Mueller, N. D.: Climate adaptation by crop migration, Nat. Commun., 11, 1243, https://doi.org/10.1038/s41467-020-15076-4, 2020.

Still, C., Powell, R., Aubrecht, D., Kim, Y., Helliker, B., Roberts, D., Richardson, A. D., and Goulden, M.: Thermal imaging in plant and ecosystem ecology: applications and challenges, Ecosphere, 10, https://doi.org/10.1002/ecs2.2768, 2019.

Suzuki, N., Rivero, R. M., Shulaev, V., Blumwald, E., and Mittler, R.: Abiotic and biotic stress combinations, New Phytol., 203, 3243, https://doi.org/10.1111/nph.12797, 2014.

Tack, J., Barkley, A., Rife, T. W., Poland, J. A., and Nalley, L. L.: Quantifying variety-specific heat resistance and the potential for adaptation to climate change, Global Change Biol., 22, 29042912, https://doi.org/10.1111/gcb.13163, 2016.

Tack, J., Barkley, A., and Hendricks, N.: Irrigation offsets wheat yield reductions from warming temperatures, Environ. Res. Lett., 12, 114027, https://doi.org/10.1088/1748-9326/aa8d27, 2017.

Thapa, S., Jessup, K. E., Pradhan, G. P., Rudd, J. C., Liu, S., Mahan, J. R., Devkota, R. N., Baker, J. A., and Xue, Q.: Canopy temperature depression at grain filling correlates to winter wheat yield in the U.S. Southern High Plains, Field Crop Res., 217, 11-19, https://doi.org/10.1016/j.fcr.2017.12.005, 2018.

van der Velde, M., Wriedt, G., and Bouraoui, F.: Estimating irrigation use and effects on maize yield during the 2003 heatwave in France, Agr. Ecosyst. Environ., 135, 90-97, https://doi.org/10.1016/j.agee.2009.08.017, 2010.

Vico, G. and Porporato, A.: Modelling C3 and C4 photosynthesis under water-stressed conditions, Plant Soil, 313, 187-203, https://doi.org/10.1007/s11104-008-9691-4, 2008.

Vico, G. and Porporato, A.: Traditional and microirrigation with stochastic soil moisture, Water Resour. Res., 46, W03509, https://doi.org/10.1029/2009WR008130, 2010.

Vico, G. and Porporato, A.: From rainfed agriculture to stressavoidance irrigation: I. A generalized irrigation scheme with stochastic soil moisture, Adv. Water Resour., 34, 263-271, https://doi.org/10.1016/j.advwatres.2010.11.010, 2011.

Vico, G. and Luan, X.: Canopy_Temp_HESS2021: v1.0, Zenodo, https://doi.org/10.5281/zenodo.4540738, 2021.

Vico, G., Manzoni, S., Palmroth, S., Weih, M., and Katul, G.: A perspective on optimal leaf stomatal conductance under $\mathrm{CO}_{2}$ and light co-limitations, Agr. Forest Meteorol., 182, 191-199, https://doi.org/10.1016/j.agrformet.2013.07.005, 2013.

Vogel, E., Donat, M. G., Alexander, L. V., Meinshausen, M., Ray, D. K., Karoly, D., Meinshausen, N., and Frieler, K.: The effects of climate extremes on global agricultural yields, Environ. Res. Lett., 14, 054010, https://doi.org/10.1088/17489326/ab154b, 2019.

Wada, Y., Van Beek, L. P., Van Kempen, C. M., Reckman, J. W., Vasak, S., and Bierkens, M. F.: Global depletion of groundwater resources, Geophys. Res. Lett., 37, L20402, https://doi.org/10.1029/2010GL044571, 2010.
Wang, Z.-Y., Li, F.-M., Xiong, Y.-C., and Xu, B.-C.: Soilwater threshold range of chemical signals and drought tolerance was mediated by ROS homeostasis in winter wheat during progressive soil drying, J. Plant Growth Regul., 27, 309, https://doi.org/10.1007/s00344-008-9057-4, 2008.

Wanjura, D., Upchurch, D., and Mahan, J.: Automated irrigation based on threshold canopy temperature, T. ASAE, 35, 153-159, https://doi.org/10.13031/2013.28748, 1992.

Way, D. A. and Yamori, W.: Thermal acclimation of photosynthesis: on the importance of adjusting our definitions and accounting for thermal acclimation of respiration, Photosynth. Res., 119, 89100, https://doi.org/10.1007/s11120-013-9873-7, 2014.

Webber, H., Ewert, F., Kimball, B. A., Siebert, S., White, J. W., Wall, G. W., Ottman, M. J., Trawally, D. N. A., and Gaiser, T.: Simulating canopy temperature for modelling heat stress in cereals, Environ. Modell. Softw., 77, 143-155, https://doi.org/10.1016/j.envsoft.2015.12.003, 2016.

Webber, H., Martre, P., Asseng, S., Kimball, B., White, J., Ottman, M., Wall, G. W., De Sanctis, G., Doltra, J., Grant, R., Kassie, B., Maiorano, A., Olesen, J. E., Ripoche, D., Rezaei, E. E., Semenov, M. A., Stratonovitch, P., and Ewert, F.: Canopy temperature for simulation of heat stress in irrigated wheat in a semi-arid environment: A multi-model comparison, Field Crop Res., 202, 21-35, https://doi.org/10.1016/j.fcr.2015.10.009, 2017.

Webber, H., White, J. W., Kimball, B. A., Ewert, F., Asseng, S., Rezaei, E. E., Pinter, P. J., Hatfield, J. L., Reynolds, M. P., Ababaei, B., Bindi, M., Doltra, J., Ferrise, R., Kage, H., Kassie, B. T., Kersebaum, K. C., Luig, A., Olesen, J. E., Semenov, M. A., Stratonovitch, P., Ratjen, A. M., LaMorte, R. L., Leavitt, S. W., Hunsaker, D. J., Wall, G. W., and Martre, P.: Physical robustness of canopy temperature models for crop heat stress simulation across environments and production conditions, Field Crop Res., 216, 75-88, https://doi.org/10.1016/j.fcr.2017.11.005, 2018.

Wu, Y., Huang, M., and Warrington, D. N.: Growth and transpiration of maize and winter wheat in response to water deficits in pots and plots, Environ. Exp. Bot., 71, 65-71, https://doi.org/10.1016/j.envexpbot.2010.10.015, 2011.

Zampieri, M., Ceglar, A., Dentener, F., and Toreti, A.: Wheat yield loss attributable to heat waves, drought and water excess at the global, national and subnational scales, Environ. Res. Lett., 12, 064008, https://doi.org/10.1088/1748-9326/aa723b, 2017.

Zhang, T., Lin, X., and Sassenrath, G. F.: Current irrigation practices in the central United States reduce drought and extreme heat impacts for maize and soybean, but not for wheat, Sci. Total Environ., 508, 331-342, https://doi.org/10.1016/j.scitotenv.2014.12.004, 2015.

Zhou, S., Duursma, R. A., Medlyn, B. E., Kelly, J. W., and Prentice, I. C.: How should we model plant responses to drought? An analysis of stomatal and non-stomatal responses to water stress, Agr. Forest Meteorol., 182, 204-214, https://doi.org/10.1016/j.agrformet.2013.05.009, 2013.

Zscheischler, J. and Seneviratne, S.: Dependence of drivers affects risks associated with compound events, Sci. Adv., 3, e1700263, https://doi.org/10.1126/sciadv.1700263, 2017. 